\title{
Volatile Compounds Analysis of Tunisian Propolis and Its Antifungal Activity
}

\author{
Ayari Jihene' ${ }^{1}$, Ines Jabri Karoui ${ }^{1}$, Ayed Ameni ${ }^{2}$, Majdi Hammami², Manef Abderrabba ${ }^{1}$ \\ ${ }^{1}$ Laboratoire Matériaux Molécules et Applications, Institut Préparatoire des Etudes Scientifiques et Techniques, IPEST, \\ La Marsa, Tunisia \\ ${ }^{2}$ Laboratoire des Substances Bioactives, Centre de Biotechnologie'a la Technopole de Borj-Cedria (CBBC), \\ Hammam-Lif, Tunisia \\ Email: jihneayari@yahoo.fr
}

How to cite this paper: Jihene, A., Karoui, I.J., Ameni, A., Hammami, M. and Abderrabba, M. (2018) Volatile Compounds Analysis of Tunisian Propolis and Its Antifungal Activity. Journal of Biosciences and Medicines, 6, 115-131. https://doi.org/10.4236/jbm.2018.66009

Received: April 29, 2018

Accepted: June 25, 2018

Published: June 28, 2018

Copyright ( $) 2018$ by authors and Scientific Research Publishing Inc. This work is licensed under the Creative Commons Attribution International License (CC BY 4.0).

http://creativecommons.org/licenses/by/4.0/

\begin{abstract}
In this study, four samples of Tunisian propolis were analyzed for their volatile compounds. Static Headspace technique coupled with gas chromatography-mass spectrometry (GC/MS) was used for the volatile profile characterization. Statistical investigation of the samples was made applying hierarchical clustering method, K-Means cluster and principal component analysis. Results showed that $47,36,30$ and 24 different compounds were identified, respectively, in the samples from Zouarine, Zelligua, Bizerte and Beni Khalled. Propolis volatiles were dominated by monoterpene hydrocarbons. $\alpha$-pinene was the major compound representing $81.14 \%, 82.67 \%$ and $90.74 \%$, respectively, of the total propolis volatiles collected from Zelligua, Beni Khalled and Zouarine and only $45.22 \%$ of the sample from Bizerte which had a very different composition. The in vitro antifungal activity of the volatiles from all samples against Candida albicans was also assayed and reported.
\end{abstract}

\section{Keywords}

Propolis, Headspace/GC-MS, $\alpha$-Pinene, PCA, Antifungal Activity

\section{Introduction}

Propolis is a resinous adhesive natural substance, collected by honeybees like (Apis mellifera L.) from buds, leaves of trees and plants then mixed with pollen and enzymes secreted by bees [1].

Propolis is used as a purpose sealer to smooth out the hive internal walls and as a barrier against intruders [2]. It is a valuable product from ancient times to nowadays. Propolis is mostly used, in folk medicine, in pharmacy and in food 
technology, as a remedy with high antioxidant, antimicrobial, antifungal, anti-inflammatory, antiviral and antitumor activities [3] [4].

Chemical composition of propolis is dependent on its botanical and geographical origin [5] [6], races of bees [7] [8] and collection season where it can be collected all year [9] [10].

Different chemical compounds including aldehydes, organic acids, esters, hydrocarbons, cyclic compounds, terpenes, flavonoid aglycones, phenolic acids and their esters, phenolic aldehydes, alcohols, ketones, sesquiterpenes, quinones, coumarins, and steroids were identified in both volatile and non-volatile propolis fractions of propolis from different botanical and geographical origin [11].

Despite the fact that volatiles are found in low contents in propolis, their pleasant aroma and significant biological activities make them very valuable for the propolis characterization [12]. Several studies showed that spread of volatile compounds identified in propolis is very wide [13] [14] [15] [16] [17]; the chemical composition depends on the specificity of the local flora at the collection region and thus on its geographic and climatic characteristics [2].

Indeed, in contrast to propolis of Europe, Algeria and Egypt, Tunisian propolis has a different botanical origin due to unique Tunisian flora which presents a generally known biodiversity with a high percentage of endemic plants [13] [18] [19] [20].

Studies regarding Tunisian propolis volatiles are very scare and limited to that of Martos et al. [21] investigation of flavonoids composition in Tunisian propolis and that of Kouidhi et al. [22] who showed that propolis ethanol extract possessed anti-cariogenic and anti-biofilm activities, and had potential protective effect against cancer cells proliferation. To the best of our knowledge, no study has been conducted concerning Tunisian propolis volatile compounds.

Candida albicans is the most well-known fungal species associated with the clinical manifestation of this pathology. It is the most prevalent and pathogenic species among all Candida infections which have become a serious health problem. As fungi grow increasingly resistant to the available drugs; new drugs must be researched and evaluated for their effectiveness in antifungal treatment [23] [24].

This strain has been selected for the basis of its application purpose of further formulation study.

So, the present work focused on the determination of Tunisian propolis volatiles and a comparative study of the volatile composition of propolis collected from different regions was performed. Samples were analyzed using static Headspace coupled with GC/MS, applying statistical data mining techniques: principal component, hierarchical clustering and K-Means cluster analysis for classification, afterwards. The in vitro antifungal activity of the volatiles from all samples against human pathogen Candida albicans was also assayed.

\section{Experimental Procedure}

\subsection{Propolis Samples}

In this study, four samples of Tunisian propolis were collected during 2014's 
spring and analyzed for their volatiles composition: two samples were collected from Kef region ( $200 \mathrm{~g}$ from Zouarine, $100 \mathrm{~g}$ from Zelligua), $100 \mathrm{~g}$ from Nabeul (Beni Khalled) and $50 \mathrm{~g}$ from Bizerte.

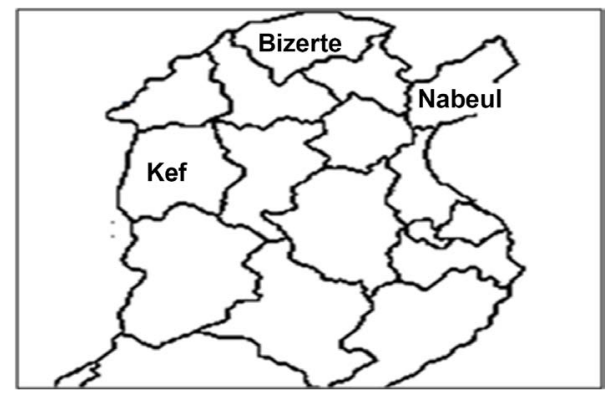

Sampling was performed based on diversity in all four regions; this difference is noticed especially with the botanical origins.

Eucalyptus, Rosemary, Thym, Citrus and Almond trees were found in both Zouarine and Zelligua sites. The Kef region is characterized by the dominance of the forests and the mountains which promoted trees diversity such as: Conifers, Birch, Ash, Yardstick, Elm, Chestnut, Poplar, Beech, Pine, Spruce, Fir, Plums and Cactus [25].

In Bizerte, bees are collecting propolis only from Orange trees and the dominant climate was steppe.

In Beni Khalled region, Rosemary, Thym, Cactus and small plants are found but there was no Eucalyptus.

\subsection{Volatile Compounds Analysis by Headspace Coupled with GC-MS}

Volatile compounds were analyzed using a Headspace (TELEDYNE TEKEMAR HT3TM) coupled with an Agilent GC-MS system (GC with 7890A, mass detector 5975C with Triple-Axis, insert XL MSD).

$1 \mathrm{~g}$ of propolis samples were introduced in a $30 \mathrm{ml}$ headspace vials incubated for $30 \mathrm{~min}$ at $80^{\circ} \mathrm{C}$ in headspace oven then transferred in heated line at $115^{\circ} \mathrm{C}$ to avoid condensation of volatiles which were injected in the GC inlet during $1 \mathrm{~min}$ with a static mode. A HP-5 ms column (5\% phenylmethylsiloxane) was used (30 $\mathrm{mm} \times 250 \mu \mathrm{m} \times 0.25 \mu \mathrm{m})$. The carrier gas was Helium $(\mathrm{N} 60=99.99 \%)$ with the flow rate of $1 \mathrm{~mL} / \mathrm{min}$.

Each run was performed during $24 \mathrm{~min}$. The temperature was programmed at $40^{\circ} \mathrm{C}$ for $1 \mathrm{~min}$, raised to $100^{\circ} \mathrm{C}$ with a rate of $10^{\circ} \mathrm{C} / \mathrm{min}$ then raised to $200^{\circ} \mathrm{C}$ with a rate of $20^{\circ} \mathrm{C} / \mathrm{min}$ and kept constant for $5 \mathrm{~min}$. It was finally raised to $300^{\circ} \mathrm{C}$ with a rate of $20^{\circ} \mathrm{C}$ and kept constant for 2 min. Injection was realized within $250^{\circ} \mathrm{C}$ inlet with a splitless mode. The auxiliary temperature was $250^{\circ} \mathrm{C}$ and the mass spectrometer was operating in EI mode $(70 \mathrm{eV})$.

Quadripole and source temperature were respectively fixed at $150^{\circ} \mathrm{C}$ and $250^{\circ} \mathrm{C}$ with a full scan mode from $40 \mathrm{~m} / \mathrm{z}$ to $550 \mathrm{~m} / \mathrm{z}$. The identification of the 
propolis components was based on a long work with NIST02 mass spectra search library.

Quantification was based on the areas of total ion current (TIC) peaks. Relative area values (percentage of total volatiles) were used for characterization purposes.

\subsection{Antifungal Activity: Propolis Effect on Candida albicans Growth}

In order to study the effect of Propolis volatiles on Candida albicans growth, an initial suspension of the yeast was done with an optical density of 0.5 on MacFarland scale (corresponding to $10^{8} \mathrm{CFU} \cdot \mathrm{ml}^{-1}$ ) and was decimally diluted with $0.9 \%(\mathrm{w} / \mathrm{v}) \mathrm{NaCl}$ to obtain an inoculum concentration of $10^{5} \mathrm{CFU} \cdot \mathrm{ml}^{-1}$. The antifungal assay was performed using the double-dish chamber method. $100 \mu \mathrm{l}$ of overnight $C$. albicans culture were spread on one half of the Petri dishes containing Sabouraud dextrose agar medium. The second half containing a scale range of Propolis concentration $1 \mathrm{mg}, 10 \mathrm{mg}, 20 \mathrm{mg}$ and $50 \mathrm{mg}$.

Plates were parafilmed and incubated for $24 \mathrm{~h}$ at $30^{\circ} \mathrm{C}$. The percentage of growth inhibition (GI) was calculated according to the following formula:

$$
G I(\%)=\frac{N_{C}-N_{1}}{N_{C}} * 100
$$

$N_{1}$ : Number of Candida colonies/box.

$N_{C}$ : Number of Candida colonies in the control box.

\subsection{Statistical Data Analysis}

For metrological repeatability of the measurements, each propolis sample was analyzed 3 times using Headspace coupled with GC-MS. According to GC-MS results, data matrix of [12 $\times 87]$ was formed for further analysis. Measured data were processed using XLSTAT2015 software. After data preparation, the following statistical methods were applied: principal component analysis (PCA), for reduction of the space of the variables; hierarchical clustering analysis (HCA) using average linkage, in order to estimate the similarity between any pair of the clusters applying average distance between all pairs of objects in any two clusters calculation; K-Means cluster analysis (KMCA), which is an iterative technique for classification that minimizes the sum, over all clusters, of the within-cluster sums of point-to-cluster-centroid Euclidean distances [26].

\section{Results and Discussion}

\subsection{Volatile Compounds Composition of Tunisian Propolis}

Visual analysis of the propolis samples showed that their color varied from golden yellow (Zouarine), opaque green (Bizerte), glossy dark brown (Zelligua) to dark (Beni Khalled) but all samples have a strong pleasant aroma. Indeed, the propolis color and odor is dependent on its botanical source [27] [28]. Bankova et al. [12] concluded that the main botanical source of European, non-tropical 
Asian and North American propolis is Populus spp.

Besides the main source, bees also use pine, linden, willow, cherry, apple and other trees [27]. In tropical regions there are no poplars; therefore bees use other plant sources for bee glue. Propolis volatiles give to the bee glue its specific pleasant aroma. It is well known that bees (Apis mellifera) respond to odors in several behavioral contexts [29] [30].

In Tunisia, different botanical sources can be found such as: Eucalyptus, Rosemary, Thym, Citrus and Orange trees. It is also characterized by the dominance of the forests around, which promotes diversity of trees where bees can collect propolis such as: conifers, birch, ash, yardstick, elm, chestnut, poplar, beech, apple, pine, spruce, fir, plums and cactus [20] [25]. Headspace-GC-MS analysis (Table 1) revealed the presence of 83 different compounds in all samples. Only 6 volatile compounds present with low proportions $(0.53 \%-0.082 \%)$ were not identified. Propolis sample collected from Zouarine was characterized by the highest number of compounds identified (47), followed by Zelligua (36) and Bizerte (30), while the lowest one was observed in the sample collected from Beni Khalled (24). The low quantity of volatile compounds identified in the Beni Khalled propolis could be due to the presence of waxes or may be related to flora.

Identified compounds mainly belonged to the class of alcohols, aldehydes, monoterpenes and sesquiterpenes. The monoterpene hydrocarbon, $\alpha$-pinene, was predominant in all samples. In fact, in Zouarine, it was a major constituent representing $90.74 \%$ of the total volatiles, followed by Beni Khalled $(82.67 \%)$, Zelligua (81.14\%) and Bizerte (45.22\%). $\beta$-pinene was found in very low percentage of $1.75 \%, 1.65 \%, 1.18 \%$ and $1.06 \%$, respectively, in the samples from Zelligua, Bizerte, Zouarine and BK.

The sesquiterpene, Cedrol, was only identified in samples of Bizerte amounting to $8.23 \%$ and Zelligua with $0.106 \%$. Propolis from Bizerte contains various compounds in small amounts varied from $1.7 \%$ to $4.53 \%$, such as 3 -methyl-2buten-1-ol, octane, tricyclene, allyl benzyl ether, 1,8-epoxy-p-menth-2-ene, $o$-cymene, $\gamma$-terpinene, $m$ mentha-3(8),6-diene, cis-sabinol, 2,3-dehydro-1,8cineole, $p$-mentha-1(7),2-dien-8-ol, 4-terpineol, $\beta$ fenchyl alcohol, $\alpha$-copaene, p-ethylguaiacol, $\beta$-copaene, junipene, $\gamma$-cadinene and (3e)-6-phenyl-3-hexen2-one.

Various compounds were identified in Zouarine sample beside $\alpha$ and $\beta$-pinene, representing low amounts, such as: sabinene, $\delta .3$ carene and limonene. In Beni Khalled sample, we found $\alpha$-thujene, 4 -terpineol, $\alpha$-terpinene, limonene, $\gamma$-terpinene, $\alpha$-terpinolene and trans-verbenol. In Zelligua we found $\alpha$-thujene, camphene, verbenene, $\delta .3$ carene and limonene.

It worth noting that all propolis samples collected from the four sites had 9 common compounds which were: $\alpha$-pinene, $\beta$-pinene, $\alpha$-thujene, o-cymene, $\alpha$-phellandrene, $\gamma$-terpinene, $\alpha$-copaene, tricyclene and 4-terpineol (Table 1) with the predominance of $\alpha$-pinene. The two propolis samples (Zouarine and Zelligua) collected from the same region of Kef presented 6 other common 
A. Jihene et al.

Table 1. Percentages of Tunisian propolis volatile compounds.

\begin{tabular}{|c|c|c|c|c|c|c|c|}
\hline $\mathrm{N}^{\circ}$ & RT & Compounds & Kovalts Index & Zouarine & Bizerte & BK & Zelligua \\
\hline 1 & 4.251 & 2-Buten-1-ol, 3-methyl- & 789 & & $3.248 \pm 0.250^{\mathrm{a}}$ & & \\
\hline 2 & 4.4 & Propanoic acid & 740 & & & & $0.094 \pm 0.055^{\mathrm{a}}$ \\
\hline 3 & 4.483 & Octane & 816 & & $3.359 \pm 0.046^{\mathrm{a}}$ & $0.499 \pm 0.124^{\mathrm{b}}$ & \\
\hline 4 & 4.972 & $\begin{array}{c}1,3,3,4- \\
\text { Tetramethylcyclopentene }\end{array}$ & 895 & & & & $0.121 \pm 0.039^{\mathrm{a}}$ \\
\hline 5 & 5.118 & Ethanone, 1-(3-ethylcyclobutyl)- & 937 & & & & $0.388 \pm 0.068^{\mathrm{a}}$ \\
\hline 6 & 6.23 & Tricyclene & 729 & $0.192 \pm 0.019^{c}$ & $1.957 \pm 0.060^{\mathrm{a}}$ & $0.503 \pm 0.124^{\mathrm{b}}$ & $0.535 \pm 0.035^{\mathrm{b}}$ \\
\hline 7 & 6.289 & $\alpha$-Thujene & 927 & $0.424 \pm 0.014^{\mathrm{d}}$ & $1.752 \pm 0.115^{\mathrm{b}}$ & $2.079 \pm 0.064^{\mathrm{a}}$ & $1.137 \pm 0.051^{\mathrm{c}}$ \\
\hline 8 & 6.427 & $\alpha$-Pinene & 934 & $90.739 \pm 1.276^{\mathrm{a}}$ & $45.217 \pm 0.007^{\mathrm{d}}$ & $82.673 \pm 2.360^{\mathrm{b}}$ & $81.140 \pm 2.310^{c}$ \\
\hline 9 & 6.557 & Dehydrosabinene & 879 & & & & $0.117 \pm 0.054^{\mathrm{a}}$ \\
\hline 10 & 6.611 & $\alpha$-Fenchene & 943 & $0.174 \pm 0.019^{\mathrm{a}}$ & & & \\
\hline 11 & 6.641 & Camphene & 950 & $0.260 \pm 0.019^{c}$ & & $0.816 \pm 0.155^{\mathrm{b}}$ & $1.149 \pm 0.067^{\mathrm{a}}$ \\
\hline 12 & 6.718 & Allyl benzyl ether & 1158 & & $2.102 \pm 0.036^{\mathrm{a}}$ & & \\
\hline 13 & 6.72 & Verbenene & 1136 & $0.193 \pm 0.019^{c}$ & & $0.472 \pm 0.137^{\mathrm{b}}$ & $1.111 \pm 0.046^{\mathrm{a}}$ \\
\hline 14 & 6.866 & Benzaldehyde & 982 & & & & $0.360 \pm 0.040^{\mathrm{a}}$ \\
\hline 15 & 6.97 & $\beta$-Cymene & 1024 & & & & $0.426 \pm 0.042^{\mathrm{a}}$ \\
\hline 16 & 7.005 & Sabinene & 973 & $1.805 \pm 0.023^{\mathrm{a}}$ & & $0.574 \pm 0.273^{\mathrm{b}}$ & \\
\hline 17 & 7.072 & $\beta$-pinene & 977 & $1.064 \pm 0.018^{\mathrm{b}}$ & $1.649 \pm 0.077^{\mathrm{b}}$ & $1.178 \pm 0.194^{\mathrm{c}}$ & $1.750 \pm 0.050^{\mathrm{a}}$ \\
\hline 18 & 7.231 & $\beta$-Myrcene & 989 & $0.051 \pm 0.016^{\mathrm{b}}$ & & $0.542 \pm 0.168^{\mathrm{a}}$ & \\
\hline 19 & 7.271 & 2,3-Dehydro-1,8-cineole & 991 & & $2.542 \pm 0.088^{\mathrm{a}}$ & & \\
\hline 20 & 7.278 & 1, 3,8-p-Menthatriene & 1030 & $0.030 \pm 0.016^{\mathrm{a}}$ & & & $0.443 \pm 0.055^{\mathrm{a}}$ \\
\hline 21 & 7.354 & Propylcyclohexane & 979 & & & & $0.313 \pm 0.055^{\mathrm{a}}$ \\
\hline 22 & 7.464 & $\alpha$-phellandrene & 1004 & $0.114 \pm 0.019^{c}$ & $1.590 \pm 0.061^{\mathrm{a}}$ & $0.386 \pm 0.119^{\mathrm{b}}$ & $0.448 \pm 0.060^{\mathrm{b}}$ \\
\hline 23 & 7.548 & $\Delta-3$ carene & 1011 & $0.944 \pm 0.020^{\mathrm{b}}$ & & $0.786 \pm 0.167^{c}$ & $1.021 \pm 0.043^{\mathrm{a}}$ \\
\hline 24 & 7.634 & $\alpha$-Terpinene & 1017 & $0.103 \pm 0.020^{c}$ & & $0.942 \pm 0.175^{\mathrm{a}}$ & $0.374 \pm 0.025^{\mathrm{b}}$ \\
\hline 25 & 7.739 & o-Cymene & 1042 & $0.197 \pm 0.021^{\mathrm{d}}$ & $2.056 \pm 0.036^{\mathrm{a}}$ & $0.602 \pm 0.177^{c}$ & $0.752 \pm 0.068^{\mathrm{b}}$ \\
\hline 26 & 7.801 & Limonene & 1029 & $0.543 \pm 0.017^{c}$ & & $1.201 \pm 0.113^{\mathrm{b}}$ & $1.416 \pm 0.034^{\mathrm{a}}$ \\
\hline 27 & 7.867 & Cis-Ocimene & 1047 & $0.026 \pm 0.012^{\mathrm{a}}$ & & & \\
\hline 28 & 8.191 & $\gamma$-Terpinene & 1059 & $0.151 \pm 0.024^{\mathrm{d}}$ & $4.533 \pm 0.087^{\mathrm{a}}$ & $0.993 \pm 0.126^{\mathrm{b}}$ & $0.816 \pm 0.045^{\mathrm{c}}$ \\
\hline 29 & 8.36 & Trans-Ocimene & 1037 & $0.025 \pm 0.016^{\mathrm{a}}$ & & & \\
\hline 30 & 8.563 & m-Mentha-3(8),6-diene & 1018 & $0.180 \pm 0.005^{\mathrm{b}}$ & $1.992 \pm 0.042^{\mathrm{a}}$ & & \\
\hline 31 & 8.567 & $\alpha$-terpinolene & 1052 & & & $0.445 \pm 0.109^{\mathrm{a}}$ & $0.414 \pm 0.052^{\mathrm{a}}$ \\
\hline 32 & 8.737 & Nonanal & 1081 & & & & $0.285 \pm 0.055^{\mathrm{a}}$ \\
\hline 33 & 8.999 & $\alpha$-Campholenal & 1155 & $0.179 \pm 0.020^{\mathrm{a}}$ & & & \\
\hline 34 & 9.001 & 3-Nonyn-1-ol & 1176 & & & & $0.153 \pm 0.057 \mathrm{a}$ \\
\hline 35 & 9.123 & Cis-limonene oxide & 1031 & $0.022 \pm 0.021^{\mathrm{a}}$ & & & \\
\hline 36 & 9.179 & Cis-sabinol & 1085 & & $4.209 \pm 0.402^{\mathrm{a}}$ & & \\
\hline
\end{tabular}




\section{Continued}

\begin{tabular}{|c|c|c|c|c|c|c|c|}
\hline 37 & 9.18 & Trans-Pinocarveol & 1131 & $0.164 \pm 0.022^{\mathrm{b}}$ & & & $0.430 \pm 0.058^{\mathrm{a}}$ \\
\hline 38 & 9.185 & Trans-Verbenol & 1118 & & & $0.534 \pm 0.095^{\mathrm{a}}$ & \\
\hline 39 & 9.238 & Camphor & 1121 & $0.030 \pm 0.013^{\mathrm{a}}$ & & & \\
\hline 40 & 9.269 & Cis Verbenol & 1119 & & & & $0.350 \pm 0.024^{\mathrm{a}}$ \\
\hline 41 & 9.279 & $\alpha$-Terpineol & 1143 & & $2.188 \pm 0.053^{\mathrm{a}}$ & & \\
\hline 42 & 9.286 & p-Mentha-1,5-dien-8-ol & 1125 & $0.056 \pm 0.017^{\mathrm{a}}$ & & & \\
\hline 43 & 9.397 & Pinocarvone & 1114 & $0.035 \pm 0.017^{\mathrm{a}}$ & & & \\
\hline 44 & 9.402 & 6-Nonynoic acid, methyl ester & 1200 & & & & $0.229 \pm 0.042^{\mathrm{a}}$ \\
\hline 45 & 9.471 & Borneol & 1166 & & & & $0.518 \pm 0.042^{\mathrm{a}}$ \\
\hline 46 & 9.479 & p-Mentha-1(7), 2-dien-8-ol & 1120 & & $3.005 \pm 0.145^{\mathrm{a}}$ & & \\
\hline 47 & 9.563 & 4-Terpineol & 1137 & $0.477 \pm 0.017^{\mathrm{d}}$ & $2.366 \pm 0.571^{\mathrm{a}}$ & $1.591 \pm 0.133^{\mathrm{b}}$ & $0.922 \pm 0.040^{c}$ \\
\hline 48 & 9.732 & $\beta$-Fenchyl alcohol & 1115 & & $3.567 \pm 0.035^{\mathrm{a}}$ & & \\
\hline 49 & 9.746 & Myrtenol & 1191 & $0.024 \pm 0.014^{\mathrm{a}}$ & & & \\
\hline 50 & 9.755 & NI 1 & 0 & & $2.975 \pm 1.191^{\mathrm{a}}$ & & $0.613 \pm 0.028^{b}$ \\
\hline 51 & 10.122 & Carvacrol Methyl Ether & 1245 & & & $0.370 \pm 0.144^{\mathrm{a}}$ & \\
\hline 52 & 10.234 & NI 2 & 0 & & $1.443 \pm 0.023^{\mathrm{a}}$ & & $0.119 \pm 0.042^{b}$ \\
\hline 53 & 10.285 & p-Ethylguaiacol & 1303 & & $2.258 \pm 0.068^{\mathrm{a}}$ & & \\
\hline 54 & 10.519 & Bornyl acetate & 1277 & $0.184 \pm 0.018^{\mathrm{a}}$ & & & \\
\hline 55 & 10.52 & $\alpha$-Fenchyl acetate & 1278 & & & $0.235 \pm 0.102^{\mathrm{a}}$ & $0.139 \pm 0.039^{b}$ \\
\hline 56 & 10.619 & NI 3 & 0 & $0.032 \pm 0.017^{\mathrm{a}}$ & & & \\
\hline 57 & 10.696 & Isopulegol & 1196 & $0.052 \pm 0.041^{\mathrm{a}}$ & & & \\
\hline 58 & 10.727 & NI 4 & 0 & & & $0.083 \pm 0.144^{\mathrm{a}}$ & \\
\hline 59 & 10.887 & Isocaryophyllene & 1494 & & $1.760 \pm 0.019^{\mathrm{a}}$ & & \\
\hline 60 & 10.928 & Methyl m-tolyl carbinol & 1169 & $0.033 \pm 0.045^{\mathrm{a}}$ & & & \\
\hline 61 & 11.035 & $\alpha$-Copaene & 1376 & $0.336 \pm 0.038^{\mathrm{b}}$ & $2.335 \pm 0.290^{\mathrm{a}}$ & $0.231 \pm 0.113^{\mathrm{b}}$ & $0.285 \pm 0.054^{\mathrm{b}}$ \\
\hline 62 & 11.263 & $\beta$-Copaene & 1433 & $0.044 \pm 0.021^{\mathrm{b}}$ & $3.203 \pm 0.030^{\mathrm{a}}$ & & \\
\hline 63 & 11.541 & Longifolene & 1398 & $0.158 \pm 0.021^{\mathrm{b}}$ & $1.781 \pm 0.016^{\mathrm{a}}$ & & \\
\hline 64 & 11.573 & $\gamma$-curcumene & 1524 & & & $0.752 \pm 0.103^{\mathrm{a}}$ & $0.478 \pm 0.053^{\mathrm{b}}$ \\
\hline 65 & 11.574 & $\alpha$-Ylangene & 1369 & $0.069 \pm 0.015^{\mathrm{a}}$ & & & \\
\hline 66 & 11.64 & Germacrene-d & 1515 & $0.024 \pm 0.026^{\mathrm{a}}$ & & & \\
\hline 67 & 11.642 & Valencene & 1474 & & & $0.191 \pm 0.100^{\mathrm{a}}$ & \\
\hline 68 & 11.943 & Junipene & 1401 & & $2.806 \pm 0.027^{\mathrm{a}}$ & & \\
\hline 69 & 11.945 & NI 5 & 0 & $0.055 \pm 0.024^{\mathrm{a}}$ & & & \\
\hline 70 & 11.951 & NI 6 & 0 & & & & $0.076 \pm 0.036^{\mathrm{a}}$ \\
\hline 71 & 11.976 & NI 7 & 0 & $0.017 \pm 0.022^{\mathrm{a}}$ & & & \\
\hline 72 & 12.113 & $\gamma$-Cadinene & 1435 & $0.023 \pm 0.037^{\mathrm{b}}$ & $2.085 \pm 0.016^{\mathrm{a}}$ & & \\
\hline 73 & 12.264 & $\Delta$-Cadinene & 1469 & & & & $0.052 \pm 0.037^{\mathrm{a}}$ \\
\hline
\end{tabular}




\section{Continued}

\begin{tabular}{|c|c|c|c|c|c|c|c|}
\hline 74 & 12.938 & Cedrol & 1543 & & $8.232 \pm 0.105^{\mathrm{a}}$ & & $0.106 \pm 0.026^{\mathrm{a}}$ \\
\hline 75 & 13.14 & NI 8 & 0 & $0.015 \pm 0.029^{\mathrm{b}}$ & $1.407 \pm 0.028^{\mathrm{a}}$ & & \\
\hline 76 & 13.238 & 1,3-Diphenylpropane & 1665 & $0.030 \pm 0.027^{\mathrm{a}}$ & & & \\
\hline 77 & 13.423 & Guaiazulene & 1472 & $0.013 \pm 0.021^{\mathrm{a}}$ & & & \\
\hline 78 & 13.626 & NI 9 & 0 & & $1.696 \pm 0.132^{\mathrm{a}}$ & & \\
\hline 79 & 13.711 & 2-Undecene & 1123 & $0.019 \pm 0.004^{\mathrm{a}}$ & & & \\
\hline 80 & 18.902 & NI 10 & 0 & $0.027 \pm 0.008^{\mathrm{a}}$ & & & \\
\hline 81 & 19.548 & NI 11 & 0 & $0.040 \pm 0.032^{\mathrm{a}}$ & & & \\
\hline 82 & 21.428 & 2-Pentene, 5-phenyl- & 1199 & $0.077 \pm 0.027^{\mathrm{a}}$ & & & \\
\hline 83 & 21.431 & (3E)-6-Phenyl-3-hexen-2-one & 1435 & $0.012 \pm 0.002^{\mathrm{b}}$ & $2.373 \pm 0.020^{\mathrm{a}}$ & & \\
\hline \multicolumn{3}{|c|}{ Total number of compound } & & 47 & 30 & 24 & 36 \\
\hline & & Total \% & & $99.461 \%$ & $100 \%$ & $98.677 \%$ & $99.078 \%$ \\
\hline
\end{tabular}

Values are given as mean \pm SD $(n=3)$. Values followed by the same letter did not share significant differences at $p<0.05$ (Duncan's test). NI: non identified compound, RT: Retention time.

compounds which were: camphene, verbenene, $\alpha$-terpinene, $\Delta .3$ carene, transpinocarveol and limonene. These similarities may be due to the close floral origin of both sites especially the distance between them that not exceed $20 \mathrm{~km}$.

Compounds such as $\beta$-pinene, limonene, $\alpha$-pinene, $\gamma$-terpinene, Cedrol, $\beta$-myrcene, $\beta$-ocimene are known to possess antimicrobial, antioxidant and antifungal activity [14] [31]. Melliou et al. [14] analyzed the antibacterial activity of Greek propolis and determined that higher antibacterial activity was observed in samples with high content of $\alpha$-pinene (45.8\%). Based on these results and since our study revealed a high content of $\alpha$-pinene, varying from $45.22 \%$ to $90.74 \%$; Tunisian propolis could possess an important antibacterial activity.

Our results on the propolis from Bizerte are in accordance with those mentioned by Melliou et al. [14] who used hydrodistillation and GC-MS for volatile extraction and analysis of Greek propolis; they showed that $\alpha$-pinene was the major constituent (45.8\%). These results were lower than our findings for the three other samples. In addition, our findings are totally different from those found on tropical propolis in which $\alpha$-pinene was present in low proportion up to $1.6 \%$ [32] [33]. However, Nunes and Guerreiro [34] performed Headspace analysis and attributed higher amounts of $\alpha$-pinene, $\beta$-pinene, sulcatone, carene, limonene, eucalyptol, $\alpha$-ocimene, $\beta$-ocimene, acetophenone and nonanal to the green Brazilian propolis. Moreover, $\alpha$-pinene composed more than a half of all volatiles in Brazilian and Uruguayan propolis and over 40\% in Iranian, Kerman and Greek ones which is lower than our results in Tunisian propolis. In the other hand, $\beta$-pinene was found in Uruguayan propolis with a higher amount (27.44\%) than $\alpha$-pinene (22.96\%), in Brazilian propolis (20.85\%), in Estonian propolis $(8.86 \%)$ and even in Greek propolis $(2.2 \%)$; these results were higher than ours [35]. 
Our results showed that Cedrol was identified in the Bizerte sample with an amount of $8.23 \%$. This was in accordance with Greek propolis [14], higher than Ethiopian propolis (2.48\%) and much lower than Brazilian one (33\%). 4-Terpineol was found in all Tunisian regions in low amounts which is different from Ethiopian propolis where it composed one of the predominant compounds (8.57\%) [15].

In Tunisian propolis, dl-limonene was found in small amounts of $0.54 \%$, $1.42 \%$ and $1.20 \%$, respectively, in the samples of Zouarine, Zelligua and Beni Khalled. These results were different comparing to Croatian [13] and Brazilian propolis from Jaguari region [36], where high percentages of dl-limonene were detected, using hydrodistillation method. This compound is known with its anti-anxious and antidepressant benefits [35] [36] [37]. $\beta$-methyl crotonaldehyde was identified as an important compound in Brazilian (10.1\%) and also in Chinese propolis [28], using Headspace analysis, but was not found in our samples.

Moreover, Eucalyptol presented a high amount of $25.95 \%$ in Estonian propolis but wasn't found in our samples. Benzaldehyde was only identified in the Tunisian propolis from Zelligua with a low amount $(0.360 \%)$. Greek propolis presented a close amount of this compound $(0.1 \%-0.3 \%)$, whereas Estonian sample contained high proportion about $10.85 \%$.

Chinese propolis was totally different than samples from Europe and South America but characterized by high amounts of 3-methyl-3-buten-1-ol and 3-methyl-2-buten-1-ol, (40.33\% and $11.57 \%$, respectively), 4-penten-1-yl acetate (9.04\%) and $\alpha$-longipinene (9.41\%) [28]. That last compound was found only in Chinese and Greek propolis and was also reported in Brazilian green propolis in high amount (24.89\%) [38]. All these compounds were not identified in our study and this might be due to the botanical, geographical and floral differences. Comparing to different European samples, a lot of similarities were found with the volatile composition of propolis from Brazil, Uruguayan, China and Greece but the nearest one to that of Tunisian propolis is the volatile composition of the Greek propolis [5] [37]. In fact, from 83 compounds, 37 are similar.

\subsection{Chemometric Analysis}

For the statistical analysis standardized, data matrix [12 $\times 87]$ was prepared as described above.

First, the PCA was applied to reduce variables in space and therefore the correlation between them. The number of principal components that will represent the data, by explaining the corresponding part of the total variance of the initial variables and will be used in further statistical analysis was chosen according to Kaiser's eigenvalue criterion [29]. In order to cluster the samples, two techniques were used: Hierarchical clustering Analysis (HCA) and K-Means clustering. The calculated distances and the results of the HCA are presented as a dendrogram in Figure 1 and Figure 2.

In fact, Figure 1 shows hierarchical cluster analysis HCA of all propolis volatile compositions. Dendograms revealed that propolis samples from Beni 


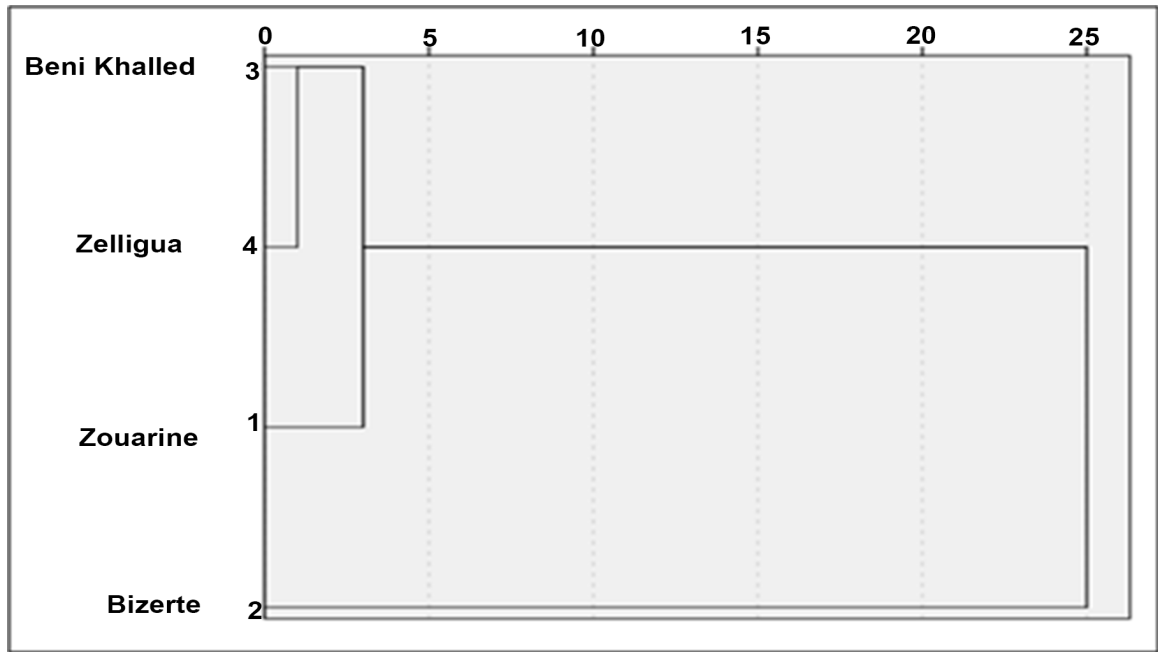

Figure 1. Dendograms of hierarchical cluster analysis HCA.

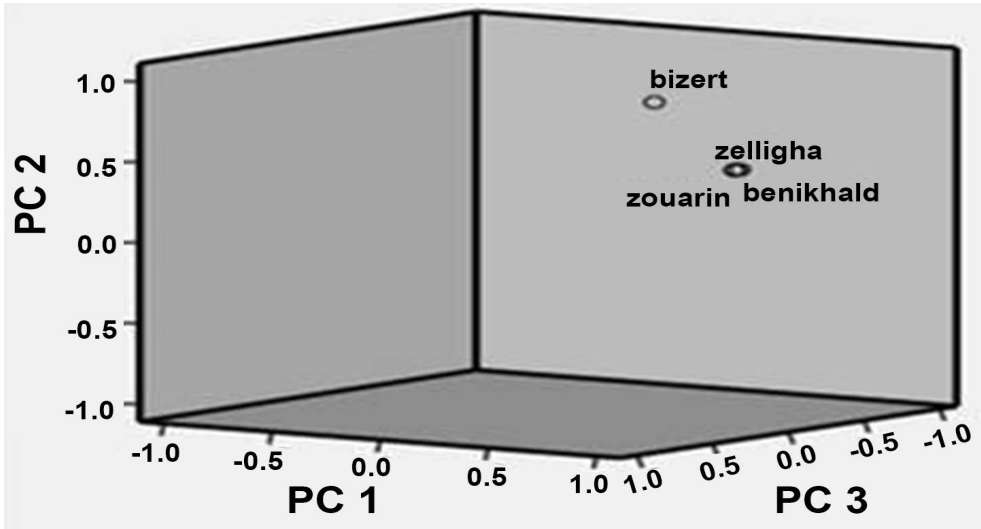

Figure 2. Plots of K-Means cluster analysis.

Khalled and Zelligua have close similarities in their composition. Propolis sample from Zouarine is different but still have some similarities with both previous samples. Finally, this analysis proved that propolis sample from Bizerte form a unique cluster, far from the others which mean, that its volatile composition is so different.

Before classification using KMCA, it is required to specify the clusters number and the iterations number to the algorithm of this analysis. The first parameter was calculated using a simple rule of thumb

$$
k=\lceil\sqrt{ }(n / 2)\rceil
$$

where operator [ 1 means rounding the result to the nearest larger integer number and $n$ is the number of the initial variables, $n=87$. The iterations number was not constant as it depends on more critical parameter (minimum Euclidean distances sum of particular classification result).

In order to find the global minimum, KMCA was programmed to run 500 times. The minimum value of the calculated minimums of the Euclidean distances sum of each run was chosen as the best classification result. The results of 
$\mathrm{KMCA}$, when $\mathrm{k}=7$, are presented as data scatter plots in three-dimensional space of first three PCA components in Figure 3.

Dendrogram in Figure 2, scatter plot in Figure 3 and diagram in Figure 4 presented clustering results. It is clearly seen that Bizerte, Zouarine, Zelligua and Beni Khalled propolis samples fall into 3 separate clusters, meaning that their volatile composition was very different. Beni Khalled and Zelligua samples formed one cluster since their volatiles composition was very similar. The sample from Zouarine formed the second cluster which is not very far from this group.

Bizerte sample had a very different composition from all other samples and constitute the third cluster. This classification is confirmed by looking to data scatter plots of K-Means cluster analysis Figure 3 which showed that Zelligua, Beni Khalled and Zouarine samples were near to each other and only the sample of Bizerte was removed from the group. For better certitude, the 9 common compounds cited above were selected for the statistical analysis and another data matrix [12 $\times 9$ ] was made. PCA for common compounds was applied and results are presented in Figure 5.

In this case, all non-common compounds with small contributions take values close to zero, and the highest common compounds having the biggest impact on the classification results are analyzed. The samples of Bizerte, Zouarine, Zelligua and Beni Khalled propolis again fall into three separate clusters. Zelligua and Beni Khalled samples are close to each other despite the difference of geographical positions of the collection sites. However, Zelligua and Zouarine samples regardless of their belonging to the same region, presented some differences in volatiles composition.

\subsection{Antifungal Activity: Propolis Effect on Candida albicans Growth}

The volatiles of all samples were also studied for their antifungal activity against a human pathogen fungus (Candida albicans).

Results in Table 2 and Figure 5 and Figure 6 showed that only volatiles from Beni Khalled and Zelligua were active against $C$. albicans. The strongest fungicidal activity was exhibited by propolis from Beni Khalled in which $10 \mathrm{mg}$ inhibited $65 \% \pm 1.96 \%$ of the growth of $C$. albicans while only $20 \mathrm{mg}$ of Zelligua's propolis inhibited $50 \% \pm 4.08 \%$ of $C$. albicans's growth; those results were compared to a control. Candida albicans growth was completely inhibited with propolis volatiles from both Beni Khalled and Zelligua at a concentration about $50 \mathrm{mg}$, respectively: $100 \% \pm 3.20 \%$ and $100 \% \pm 1.60 \%$.

The chemometric analysis revealed that volatile composition of propolis from Beni Khalled and Zelligua were similar and have 18 common compounds, as proved in Figure 4 from the PCA analysis, this similarity may explain the antifungal activity of both propolis samples compared to the propolis samples from other regions in which no activity were observed even in higher concentrations. 
D1 and D2 : 80,77\%

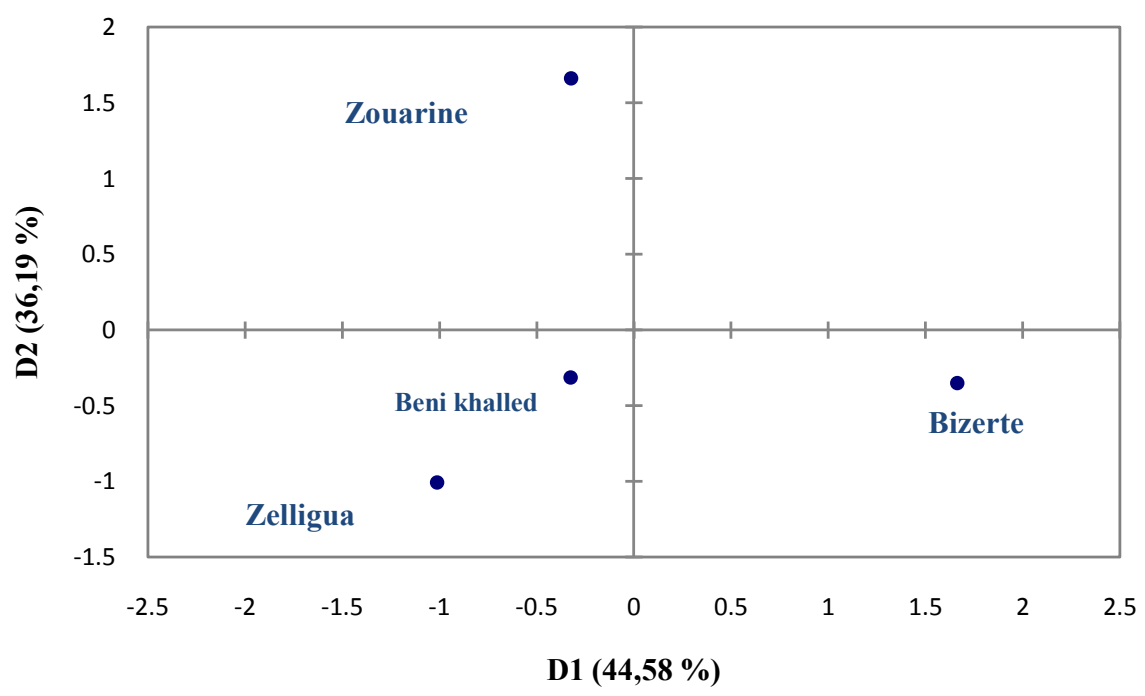

Figure 3. PCA presentation of compounds in propolis.

$\mathrm{F} 1$ et $\mathrm{F} 2: 91,61 \%$

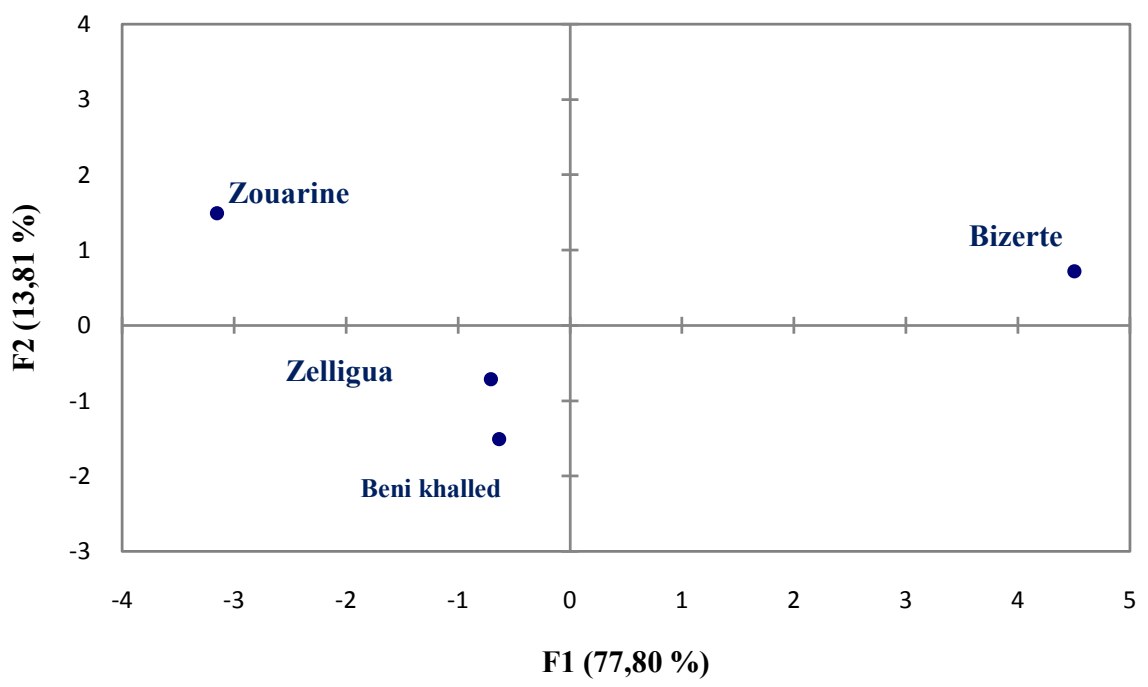

Figure 4. PCA for common compounds in all propolis samples.

The observed antifungal activity is probably due to the high amounts of $\alpha$-pinene in propolis from Zelligua and Beni Khalled, respectively $(81.140 \%$ 82.673\%) which is well known to possess similar antifungal and antimicrobial activities [39]. This hypothesis cannot be confirmed since volatiles in propolis from the region of Zouarine contained higher amount of $\alpha$-pinene reaching $90.739 \%$ and although it was not active against Candida. Those conclusions may give us the confirmation that only a synergy between compounds found in propolis from both regions can lead to the antifungal activity observed.

Comparing all compounds between active and inactive propolis samples, we found that three compounds were found in common in both Beni Khalled and 
Table 2. Growth inhibition of $C$. albicans by propolis VOCs.

\begin{tabular}{cccc}
\hline \multicolumn{2}{c}{ Propolis from Beni Khalled } & \multicolumn{2}{c}{ Propolis from Zelligua } \\
\hline Concentration (mg) & Growth inhibition (\%) & Concentration (mg) & Growth inhibition (\%) \\
\hline 10 & $65 \pm 1.96$ & 20 & $50 \pm 4.08$ \\
50 & $100 \pm 3.20$ & 50 & $100 \pm 1.60$ \\
\hline
\end{tabular}

Values are the means of inhibitory rate SD, means based on 3 replicates.

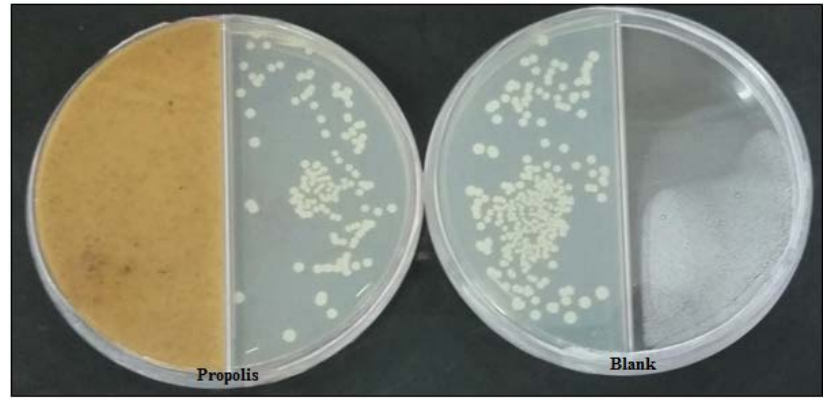

(a)

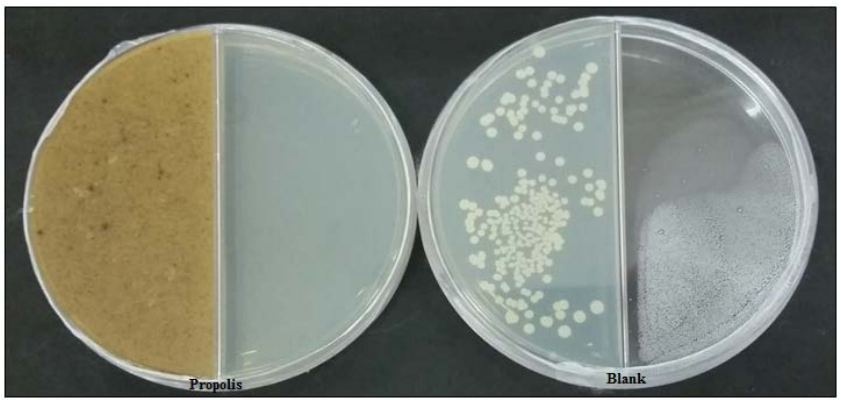

(b)

Figure 5. Effect of VOCs of Beni Khalled propolis against C. albicans. (a) Effect of $10 \mathrm{mg}$ of propolis against $C$. albicans growth; (b) Effect of $50 \mathrm{mg}$ of propolis against $C$. albicans growth.

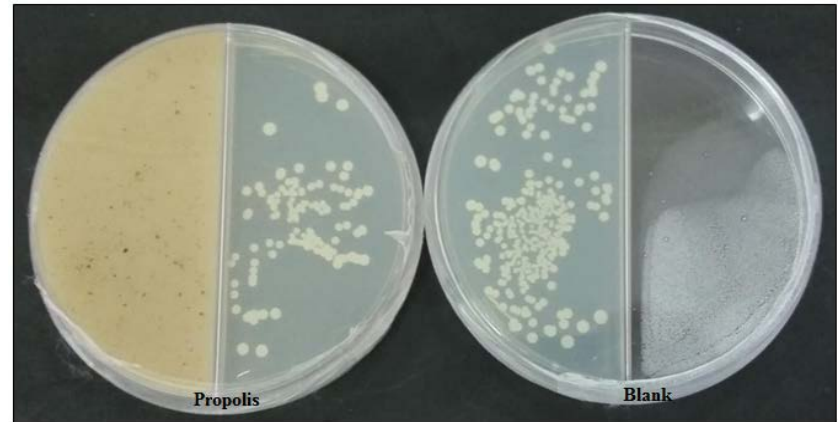

(a)

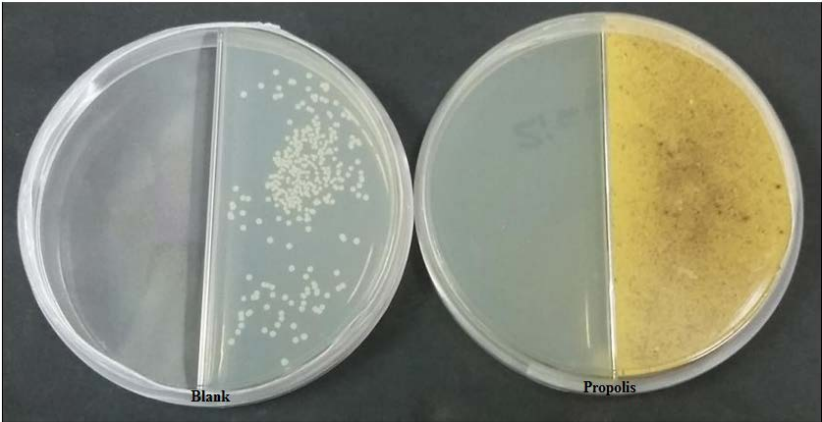

(b)

Figure 6. Effect of VOCs of Zelligua propolis against $C$. albicans. (a) Effect of $20 \mathrm{mg}$ of propolis against $C$. albicans growth; (b) Effect of $50 \mathrm{mg}$ of propolis against $C$. albicans growth.

Zelligua samples which are $\alpha$-terpinolene, $\gamma$-curcumene and $\alpha$-Fenchyl acetate $(0.445 \%, 0.414 \% ; 0.752 \%, 0.478 \%$ and $0.235 \%, 0.139 \%$, respectively). Those compounds are known for their strong antifungal activities as shown in some previous studies [37] [40].

Further tests on the anti candida albicans activity of common compounds in active propolis samples may prove to us weather this antifungal activity is due only to one of those compounds, a synergy of all three or a synergy between all volatile compounds in propolis.

\section{Conclusions}

The present work provides first data about the Tunisian propolis volatiles and reveals its interesting character. 
Headspace GC-MS analysis showed the presence of different compounds in all propolis samples with the predominance of $\alpha$-pinene which is known for its several biological activities. The statistical analysis applied for the propolis volatiles composition showed a notable variation between all samples. This difference is mainly related to the local flora, geographic and climatic characteristics of the site. As far as it concerns the antifungal activity, it should be noted that the active samples showed minor differences in their activities independently from their geographic origin or chemical consistency. Results showed that due to the important number and the diversity of its volatile compounds, Tunisian propolis could be used as a potential source of natural volatiles which play important role by contributing to the pleasant aroma and biological activity of propolis.

\section{Acknowledgements}

The authors are grateful to Mr. Farid Limam chief head of the biological department of Borj Cedria Tunisia. We also thank Mr. Bilel Garbouj from the Bee House Beni Khalled, Mr. Anis Mejri and Mr. Khaled Zaghmouri for providing the Propolis samples from Zelligua and Zouarine sites.

\section{Competing Interest}

The authors declare that they have no competing interests.

\section{Funding Statement}

The authors declare that no funding was received.

\section{References}

[1] Marcucci, M.C. (1995) Propolis: Chemical Composition, Biological Properties and Therapeutic Activity. Apidologie, 26, 83-99. https://doi.org/10.1051/apido:19950202

[2] Burdock, G.A. (1998) Review of the Biological Properties and Toxicity of Bee Propolis. Food and Chemical Toxicology, 36, 347-363. https://doi.org/10.1016/S0278-6915(97)00145-2

[3] Alencar, S.M., Oldoni, T.L., Castro, M.L., Cabral, I.S., Costa-Neto, C.M., Cury, J.A., Rosalen, P.L. and Ikegaki, M. (2007) Chemical Composition and Biological Activity of a New Type of Brazilian Propolis: Red Propolis. Journal of Ethnopharmacology, 113, 278-283. https://doi.org/10.1016/j.jep.2007.06.005

[4] Sforcin, J.M. (2007) Propolis and the Immune System: A Review. Journal of Ethnopharmacology, 113, 1-14. https://doi.org/10.1016/j.jep.2007.05.012

[5] Kalogeropoulos, N., Konteles, S.J., Troullidou, E., Mourtzinos, I. and Karathanos, V.T. (2009) Chemical Composition, Antioxidant Activity and Antimicrobial Properties of Propolis Extracts from Greece and Cyprus. Food Chemistry, 116, 452-461. https://doi.org/10.1016/j.foodchem.2009.02.060

[6] Lu, L.C., Chen, Y.W. and Chou, C.C. (2005) Antibacterial Activity of Propolis against Staphylococcus aureus. International Journal of Food Microbiology, 102, 213-220. https://doi.org/10.1016/j.ijfoodmicro.2004.12.017

[7] da Cunha, M.G., Franchin, M., Galvão, L., de Ruiz, A., de Carvalho, J.E., Ikegaki, M., de Alencar, S.M., Koo, H. and Rosalen, P.L. (2013) Antimicrobial and Antipro- 
liferative Activities of Stingless Bee Melipona scutellaris Geopropolis. BMC Complementary and Alternative Medicine, 13, 23. https://doi.org/10.1186/1472-6882-13-23

[8] Silici, S. and Kutluca, S. (2005) Chemical Composition and Antibacterial Activity of Propolis Collected by Three Different Races of Honeybees in the Same Region. Journal of Ethnopharmacology, 99, 69-73. https://doi.org/10.1016/j.jep.2005.01.046

[9] Bankova, V., Boudourova-Krasteva, G., Popov, S., Sforcin, J.M. and Funari, S.R.C. (1998) Seasonal Variations in Essential Oil from Brazilian Propolis. Journal of Es sential Oil Research, 10, 693-696. https://doi.org/10.1080/10412905.1998.9701012

[10] Sforcin, J.M., Fernandes, A., Lopes, C.A.M., Bankova, V. and Funari, S.R.C. (2000) Seasonal Effect on Brazilian Propolis Antibacterial Activity. Journal of Ethnopharmacology, 73, 243-249. https://doi.org/10.1016/S0378-8741(00)00320-2

[11] Bankova, V. (2009) Chemical Diversity of Propolis Makes It a Valuable Source of New Biologically Active Compounds. Journal of ApiProduct and ApiMedical Science, 1, 23-28. https://doi.org/10.3896/IBRA.4.01.2.01

[12] Bankova, V.S., de Castro, S.L. and Marcucci, M.C. (2000) Propolis: Recent Advances in Chemistry and Plant Origin. Apidologie, 31, 3. https://doi.org/10.1051/apido:2000102

[13] Borcic, I., Radonic, A. and Grzunov, K. (1998) and Comparison of the Volatile Constituents of Propolis Gathered in Different Regions of Croatia. Flavour and Fragrance Journal, 11, 311-313. https://doi.org/10.1002/(SICI)1099-1026(199609)11:5<311::AID-FFJ581>3.0.CO;2-X

[14] Melliou, E., Stratis, E. and Chinou, I. (2007) Volatile Constituents of Propolis from Various Regions of Greece-Antimicrobial Activity. Food Chemistry, 103, 375-380. https://doi.org/10.1016/j.foodchem.2006.07.033

[15] Haile, K., Kebede, T. and Dekebo, A. (2012) A Comparative Study of Volatile Components of Propolis (Bee Glue) Collected from Haramaya. Bulletin of the Chemical Society of Ethiopia, 26, 353-360. https://doi.org/10.4314/bcse.v26i3.4

[16] Pino, J.A., Marbot, R., Delgado, A., Zumárraga, C. and Sauri, E. (2006) Volatile Constituents of Propolis from Honey Bees and Stingless Bees from Yucatan. Journal of Essential Oil Research, 18, 53. https://doi.org/10.1080/10412905.2006.9699384

[17] Kaškonienė, V., Kaškonas, P., Maruška, A. and Kubilienė, L. (2014) Chemometric Analysis of Volatiles of Propolis from Different Regions Using Static Headspace GC-MS. Central European Journal of Chemistry, 12, 736-746. https://doi.org/10.2478/s11532-014-0521-7

[18] Naik, D.G., Vaidya, H.S. and Namjoshi, T.P. (2013) Essential Oil of Indian Propolis: Chemical Composition and Repellency against the Honeybee Apisflorea. Chemistry \& Biodiversity, 10, 649-657. https://doi.org/10.1002/cbdv.201200165

[19] Bankova, V., Christov, R., Pureb, O. and Bocari, G. (1994) Volatile Constituents of Propolis. Zeitschrift für. Naturforschung, 49, 6-10.

https://doi.org/10.1515/znc-1994-1-202

[20] Segueni, N., Khadraoui, F., Moussaoui, F., Zellagui, A., Guerraf, N., Lahouel, M. and Rhouati, S. (2010) Volatils Constituents of Algerian Propolis. Annals of Biological Research, 1, 103-107.

[21] Martos, I., Cossentini, M., Ferreres, F. and Tomás-Barberán, F.A. (1997) Flavonoid Composition of Tunisian Honeys and Propolis. Journal of Agricultural Food Chemistry, 45, 2824-2829. https://doi.org/10.1021/jf9609284

[22] Kouidhi, B., Zmantar, T. and Bakhrouf, A. (2010) Anti-Cariogenic and Anti-Bio- 
films Activity of Tunisian Propolis Extract and Its Potential Protective Effect against Cancer Cells Proliferation. Anaerobe, 16, 566-571. https://doi.org/10.1016/j.anaerobe.2010.09.005

[23] Marcos-Arias, C., Eraso, E., Madariaga, L. and Quindós, G. (2011) In Vitro Activities of Natural Products against Oral Candida Isolates from Denture Wearers. BMC Complementary and Alternative Medicine, 11, 119. https://doi.org/10.1186/1472-6882-11-119

[24] Iosif, L., Preoteasa, C.T., Murariu-Maqureanu, C. and Preoteasa, E. (2016) Clinical Study on Thermography, as Modern Investigation Method for Candida-Associated Denture Stomatitis. Romanian Journal of Morphology and Embryology, 57, 191-195.

[25] Barbouche, N. (2009) La filiére apicole en Tunisie, situation, contraintes et perspectives. Institut National d'agriculture, Barkane.

[26] XLSTAT 2015 Software.

[27] De Albuquerque, I.L., Alves, L.A., Lemos, T.L.G., Dorneles, C.A. and de Morais, M.O. (2008) Constituents of the Essential Oil of Brazilian Green Propolis from Brazil. Journal of Essential Oil Research, 20, 414-415.

[28] Cheng, H., Qin, Z.H., Guo, X.F., Hu, X.S. and Wu, J.H. (2013) Geographical Origin Identification of Propolis Using GC-MS and Electronic Nose Combined with Principal Component Analysis. Food Research International, 51, 813. https://doi.org/10.1016/j.foodres.2013.01.053

[29] Winston, M.L. (1987) The Biology of Honey Bees. Harvard University Press, Cambridge.

[30] Getz, W.M. and Page, R.E. (1991) Chemosensory Kin-Communication Systems and Kin Recognition in Honey Bees. Ethology, 87, 298-315. https://doi.org/10.1111/j.1439-0310.1991.tb00254.x

[31] Dorman, H.J.D. and Deans, S.G. (2008) Antimicrobial Agents from Plants: Antibacterial Activity of Plant Volatile Oils. Journal of Applied Microbiology, 88, 308-316. https://doi.org/10.1046/j.1365-2672.2000.00969.x

[32] Oliveira, A.P., França, H.S., Kuster, R.M., Teixeira, L.A. and Rocha, L.M. (2010) Chemical Composition and Antibacterial Activity of Brazilian Propolis Essential Oil. Journal of Venomous Animals and Toxins including Tropical Diseases, 16, 121-130. https://doi.org/10.1590/S1678-91992010005000007

[33] Maróstica Junior, M.R., Daugsch, A., Moraes, C.S., Queiroga, C.L., Pastore, G.M. and Park, Y.K. (2008) Brazilian Red Propolis-Chemical Composition and Botanical Origin. Ciência e Tecnologia de Alimentos, 28, 178. https://doi.org/10.1590/S0101-20612008000100026

[34] Nunes, C.A. and Guerreiro, M.C. (2012) Characterization of Brazilian Green Propolis throughout the Seasons by Headspace GC/MS and ESI-MS. Journal of the Science of Food and Agriculture, 92, 433-438. https://doi.org/10.1002/jsfa.4596

[35] Silva, V., Genta, G., Möller, M.N., Masner, M., Thomson, L., Romero, N., Radi, R., Fernandes, D.C., Laurindo, F.R., Heinzen, H., Fierro, W. and Denicola, A. (2011) Antioxidant Activity of Uruguayan Propolis. In Vitro and Cellular Assays. Journal of Agricultural and Food Chemistry, 59, 6430-6437. https://doi.org/10.1021/jf201032y

[36] Simionatto, E., Facco, A.T., Morel, A.F., Giacomelli, S.R. and Linares, C.E.B. (2012) Chiral Analysis of Monoterpenes in Volatile Oils from Propolis. Journal of the Chilean Chemical Society, 57, 1240-1243. https://doi.org/10.4067/S0717-97072012000300009

[37] Zhou, H., Tao, N. and Jia, L. (2014) Antifungal Activity of Citral, Octanal and 
$\alpha$-Terpineol against Geotrichum citri-aurantii. Food Control, 37, 277-283. https://doi.org/10.1016/j.foodcont.2013.09.057

[38] Li, Y.J., Xuan, H.Z., Shou, Q.Y., Zhan, Z.G., Lu, X. and Hu, F.L. (2012) Therapeutic Effects of Propolis Essential Oil on Anxiety of Restraint-Stressed Mice. Human \& Experimental Toxicology, 31, 157-165. https://doi.org/10.1177/0960327111412805

[39] Magiatis, P., Melliou, E., Skaltsounis, A.-L., Chinou, I. and Mitaku, S. (1999) Chemical Composition and Antimicrobial Activity of the Essential Oils of Pistacia lentiscus var. chia. Planta Medica, 65, 749-752. https://doi.org/10.1055/s-2006-960856

[40] Hartati, R., Suganda, A.G. and Fidrianny, I. (2015) Chemical Composition and Antimicrobial Activity of Diterpene and Essential Oils of Hedychium roxburghii Blume Rhizome. Asian Journal of Pharmaceutical and Clinical Research, 8, 221-226. 